\title{
PEMBAHARUAN HUKUM KELUARGA SERTA DAMPAKNYA TERHADAP PEMBATASAN USIA MINIMAL KAWIN DAN PENINGKATAN STATUS WANITA
}

\author{
M. Nur Hasan Latief \\ Pengadilan Agama Wates \\ Email: nurhasan83@yahoo.co.id
}

\begin{abstract}
ABSTRAK
Hukum keluarga Islam pada pertengahan abad ke 20 mulai mengalami reformasi. Turki menjadi negara pertama yang mereformasi hukum keluarga diikuti oleh Mesir. Hingga saat ini hukum keluarga Islam terus mengalami pembaharuan. Keberanjakan hukum keluarga Islam dari fikih konvensional menuju undangundang kontemporer disebabkan aturan dalam kitab fikih konvensional dianggap sudah tidak mampu lagi memberikan solusi terhadap berbagai masalah yang ada. Pembaharuan hukum Islam mempunyai berbagai tujuan yang salah satunya yaitu untuk untuk melindungi dan meningkatkan derajat kaum perempuan juga memperkuat hak-hak anggota keluarga. Berbagai peraturan diterapkan untuk melindungi hak-hak perempuan. Salah satunya yaitu dengan membatasi usia minimal perempuan boleh kawin.
\end{abstract}

Kata Kunci: pembaharuan hukum keluarga, usia minimal kawin, status perempuan

\section{ABSTRACT}

The Islamic family law in the mid-20th century began to undergo reformation. Turkey became the first country to reform family law followed by Egypt. Until now, the Islamic family law continues to be subjected to amendment. The development of Islamic family law from the conventional fiqh to contemporary law is because the rule in fiqh is conventionally considered no longer able to provide solutions to various problems. The amendment of Islamic law has a great variety of purposes, one of which is to protect and to amend the status of women also to strengthen the rights of family members. Various policies are implemented to protect the rights of women, one of them is by limiting the marriageable age of women.

Keywords: Amendment of family law, minimum marriage age, and the status of women

\section{A. LATAR BELAKANG}

Dewasa ini hukum keluarga memiliki kontribusi yang tidak sedikit dalam pembentukan sistem hukum. Ini dikarenakan hukum keluarga mengalami perkembangan dan pertumbuhan yang selaras dengan kehidupan manusia. Sebagai makhluk pribadi dan sosial, manusia senantiasa mengalami perubahan budaya dan tradisi yang dijalankan sehari-hari. Hal tersebut tentunya membawa dampak juga terhadap norma hukum yang dianut selama ini. Berbagai peraturan yang menyangkut masalah yang berkaitan dengan sistem keluarga juga mengalami perkembangan, mulai yang masalah perkawinan, perceraian, dan hak asuh anak. 
Berbagai persoalan yang berkaitan dengan masalah keluarga terus mengalami perkembangan seiring dengan perkembangan zaman dan teknologi. Hal ini kemudian menuntut instrumen hukum yang ada harus bisa mengakomodir bermacam persoalan yang muncul tersebut agar bisa diselesaikan. Selain itu, isu gender turut membawa perubahan terhadap kedudukan seorang wanita dalam hukum terutama dalam sistem hukum keluarga. Kedudukan Wanita yang dahulu selalu di nomor duakan, sekarang menjadi setara dengan laki laki, sehingga membawa perubahan terhadap masalah peran dan tugas wanita dalam kehidupan rumah tangga. Adanya kedudukan yang setara tersebut membawa perubahan yang cukup besar dalam sistem hukum keluarga.

Hukum keluarga yang berlaku antara satu negara dengan negara lainnya tentu berbeda, termasuk hukum keluarga yang berlaku di beberapa negara muslim. Meskipun yang menjadi acuan hukum keluarga di negara-negara muslim adalah hukum Islam, namun pemaknaan serta interpretasi hukum Islam juga memiliki perbedaan. Hal ini bisa kita lihat dari pluralitas hukum keluarga yang ada di beberapa negara muslim.

Seiring dengan perkembangan zaman, maka negara-negara muslim kemudian melakukan pembaharuan hukum keluarga untuk mengakomodir berbagai persoalan yang muncul. Pembaharuan ini selanjutnya menjadi tonggak awal reformasi hukum keluarga yang merata di negara-negara muslim.

Pada abad 20, sejarah panjang pembaruan Hukum Keluarga Islam di dunia dimulai. Turki menjadi negara pertama pelopor pembaharuan tersebut dengan mereformasi Hukum Keluarga Islam dan melahirkan Ottoman Law of Family Right tahun 1917 sampai pada akhirnya mengadopsi Hukum Sipil Swiss sebagai UndangUndang Turki pada tahun 1926. Pembaruan hukum keluarga yang dilakukan oleh berbagai negara muslim secara garis besar mencakup tiga aspek, yaitu perkawinan, perceraian, dan warisan. Tujuan pembaharuan Hukum Keluarga Islam Kontemporer secara umum dapat dikelompokkan menjadi tiga, yakni: (1) Unifikasi hukum; (2) Peningkatan Status Perempuan, dan; (3) Merespon perkembangan dan tuntutan zaman karena doktrin fikih tradisional yang dianggap kurang mampu menjawab masalah yang berkembang di masyarakat (Nasution, 2010: 40).

Kajian pembaruan Hukum Keluarga Islam ini didahului dengan uraian mengenai sejarah pembaruan Hukum Keluarga Islam, dimulai dari negara yang berperan besar dalam reformasi Hukum Keluarga Islam. Selanjutnya adalah bentuk dan tujuan pembaruan dan penerapannya di Indonesia. Selain itu adalah studi terkait perempuan dan batas usia minimal kawin dan pengaruh pembaruan Hukum Keluarga Islam yang terfokus pada kajian pengangkatan satus perempuan.

\section{B. PEMBAHASAN}

\section{Sejarah pembaruan Hukum Keluarga Islam}

Negara Turki merupakan negara pertama yang melakukan pembaruan hukum keluarga dalam bentuk undang-undang. Menurut Seyyed Hossein Nasr dalam Arvind Sharma Our Religion, bagi muslim Turki, Hanafi adalah mazhab yang melatari 
kehidupan keberagamaan secara formal hingga tahun 1926 (Nasution, 2012: 82). Pembaruan hukum keluarga di Turki juga telah mengalami perkembangan yang cukup pesat dibandingkan dengan fikih konvensional di mana tujuannya adalah aktualisasi hukum yang terus berkembang.

Setelah Turki, Republik Arab Mesir mengikuti pembaruan hukum keluarga. Lain halnya dengan Turki yang mengadopsi hukum Code Civil Switzerland, Republik Arab Mesir memperbaruinya dengan melakukan reformasi terhadap hukum-hukum fikih yang telah berlaku. Mesir menjadi negara pertama di Arab dan negara kedua setelah Turki yang mengadakan pembaruan hukum keluarga (Jamaluddin, 2013: 1).

Pembaruan hukum keluarga di Mesir dimulai tahun 1920 ditandai dengan diundangkannya Rancangan Undang-Undang Hukum Keluarga. Pada tahun 1929 dilakukan amandemen kedua terhadap beberapa pasal pada undang-undang sebelumnya. Setelah itu tercatat dua kali amandemen terhadap hukum keluarga Mesir yaitu pada tahun 1979 dan 1985. Reformasi hukum keluarga Mesir antara lain terkait dengan masalah poligami, wasiat wajibah, warisan, dan pengasuhan anak. Pasal 13 Kitab undang-Undnag Acara Peradilan Mesir menyebutkan bahwa al-Ahwal as-Syakhsiyyah menyangkut masalah-masalah yang berhubungan dengan pribadi, ahliyyah dan keluarga (seperti perkawinan dan akibat hukumnya, pengampuan, orang maqfud dan harta warisan) (Jamaluddin, 2013: 1).

Kontribusi nyata yang dilakukan Turki dan Mesir dalam hal ini yaitu ada pada pengaruh kedua negara tersebut, sehingga dijadikan pembuka sekaligus rujukan bagi pembaruan Hukum Keluarga Islam yang relevan terhadap perkembangan zaman, dan demi mencapai tujuan aktualisasi hukum sehingga bisa adaptif dan seresponsif mungkin terhadap problematika dinamis (Jamaluddin, 2013: 2).

Dari sejarahnya, menurut J.N. Anderson terdapat tiga tiga tipologi negara muslim berdasarkan pembaruan hukum Islam yang dilakukan (Jamaluddin, 2013: 2):

a. Negara muslim yang sama sekali tidak mau melakukan pembaruan dan masih tetap memberlakukan hukum keluarga sebagimana yang tertuang dalam kitab-kitab fikih dari mazhab yang dianut. Saudi Arabia merupakan contoh dari negara muslim yang termasuk kategori ini;

b. Negara muslim yang sama sekali telah meninggalkan hukum keluarga Islam (fikih) dan sebagai gantinya mengambil hukum sipil Eropa. Turki yang menganut hukum sipil dari Swiss adalah contoh negara yang termasuk kelompok ini, dan;

c. Negara-negara muslim yang berusaha memberlakukan hukum keluarga Islam setelah mengadakan pembaruan. Negara yang termasuk kelompok ini misalnya adalah Mesir, Tunisia, Pakistan, dan Indonesia.

\section{Bentuk dan Tujuan Pembaharuan Hukum Keluarga Islam}

Bentuk pembaruan hukum keluarga Islam ini ada dua yaitu Intra Doctrinal Reform dan Extra Doctrinal Reform. https://syakhsiyah.wordpress.com diunduh pada 27 juni 2016.

a. Intra Doctrinal Reform 
Pembaruan yang masih berkisar pada pendapat-pendapat imam mazhab, dengan model:

1) Talfiq : mencampuradukkan dengan undang-undang

2) Tahayyur: tetap pada satu mazhab yang diikuti

\section{b. Extra Doctrinal Reform}

Pola pembaruan yang sudah keluar dari imam mazhab, contohnya yaitu poligami dilarang di Mesir dan Tunisia padahal dalam al-Quran tidak dilarang. Pola ini memiliki beberapa metode https://syakhsiyah. wordpress.com/ diunduh pada 27 juni 2016.

1) Metode siyasah syar'iyah

2) Interpretasi nas.

Sedangkan tujuan dari pembaruan hukum keluarga Islam dapat dikelompokkan menjadi tiga, yaitu unifikasi hukum, pengangkatan status perempuan dan penyesuaian fikih dengan perkembangan zaman. Kelompok yang dimaksud adalah sebagai berikut:

a. Unifikasi Hukum

Unifikasi hukum adalah upaya penyatuan hukum menjadi satu hukum yang berlaku bagi rakyat yang ada di seluruh wilayah negara dan menjadi bagian dari sistem hukum nasional. Usaha unifikasi hukum ini dilakukan karena masyarakatnya menganut bermacam-macam mazhab atau bahkan agama yang berbeda. Alasan pembaruan untuk unifikasi ini adalah karena adanya sejumlah mazhab yang diikuti oleh negara yang bersangkutan. Unifikasi hukum ini memiliki beberapa pemberlakuan, yaitu:

1) Unifikasi berlaku utuk muslim dan non-muslim;

2) Unifikasi berlaku untuk muslim dengan menyatukan dua aliran besar dalam Islam yaitu sunni dan syiah. Seperti contohnya negara Irak dan Iran;

3) Unifikasi berlaku untuk muslim dengan memberlakukan antar mazhab di kalangan sunni;

4) Unifikasi untuk muslim saja dalam bentuk satu mazhab saja, dijadikan sebagai mazhab yang terkait dengan negara, seperti halnya dengan:

a) Fikih adalah pemikiran yang tidak dijadikan undang-undang/tidak mengikat

b) Qonun adalah fikih taqnin, pemahaman yang dijadikan undangundang

c) Yurisprudensi adalah pemahaman hakim terdahulu, dapat dijadikan rujukan pakar-pakar hukum yang lain

d) Fatwa adalah pemahaman terhadap suatu perkara yang muncul stelah adanya perkara

1) Tujuan peningkatan status perempuan

Tujuan ini memang tidak disebutkan secara gamblang, namun terlihat dari materi hukum yang dirumuskan bahwa undang-undang tersebut merespon sejumlah tuntutan peningkatan status dan kedudukan 
perempuan. Hampir semua pembaharuan undang-undang perkawinan di berbagai negara dilakukan untuk meningkatkan ststus perempuan.

2) Tujuan menyesuaikan dengan perkembangan zaman

Agar tidak tertinggal dengan perubahan zaman yang terus menerus terjadi, maka perlu pembaruan hukum keluarga Islam untuk mengimbanginnya. Dapat dikatakan bahwa tujuan ketiga ini merupakan tujuan dari pembaruan hukum keluarga dari kebanyakan negara muslim, meskipun tidak menutup kemungkinan di beberapa negara mencakup berbagai tujuan sekaligus.

Perubahan yang terjadi dalam sistem hukum yang telah lama digunakan pasti membawa dampak yang sangat besar bagi masyarakat. Termasuk hukum keluarga Islam di negara muslim, khususnya Indonesia. Sikap para ulama pun juga pro dan kontra dan tak jarang terjadi perdebatan sengit karena ingin mempertahankan ketentuan hukum yang lama, baik karena persoalan metodologi maupun substansinya.

Isu-isu pokok undang-undang Islam yang mengalami pembaruan hukum di antaranya adalah: pertama, masalah pembatasan umur minimal kawin yang menjadi isu sangat penting karena berhubungan dengan kedewasaan seseorang; Kedua, masalah peranan wali dalam akad nikah; Ketiga, masalah pendaftaran dan pencatatan perkawinan. Ini penting karena perkawinan di bawah tangan masih dilakukan oleh sebagian umat Islam; Keempat, masalah keuangan perkawinan (mas kawin dan biaya perkawinan) yang berhubungan dengan kondisi ekonomi seseorang; Kelima, masalah poligami, hak-hak istri dalam poligami, dan kerelaan istri sebelumnya; Keenam, masalah nafkah istri dan keluarga serta rumah tinggal; Ketujuh, masalah talak cerai dan cerai di muka pengadillan; Kedelapan, masalah hakhak perempuan yang dicerai suaminya; Kesembilan, masalah masa hamil dan akibat hukumnya; Kesepuluh, masalah hak dan tanggungjawab pemeliharaan anak-anak setelah terjadi perceraian; Kesebelas, masalah hak waris bagi anak laki-laki dan perempuan, termasuk anak dari anak yang terlebih dahulu meninggal; Kedua belas, masalah wasiat bagi ahli waris; Ketiga belas, masalah keabsahan dan pengelolaan wakaf keluarga (Nasution, 2010: 42).

\section{Pembaruan Hukum Keluarga Islam di Indonesia}

Pembaruan hukum keluarga Islam Indonesia dimulai tahun 1960an yang menghasilkan UU No. 1 tahun 1974 tentang Perkawinan. UU No. 1 tahun 1974 ini adalah undang-undang pertama di Indonesia yang mengatur tentang perkawinan secara nasional. Sebelumnya, masalah perkawinan diatur melalui berbagai macam hukum, yaitu (Prodjodikoro, tt: 77):

a. Hukum adat bagi warga negara Indonesia asli

1) Hukum Islam bagi warga negara Indonesia asli yang beragama Islam;

2) Ordonansi perkawinan Indonesia Kristen bagi warga negara Indonesia yang beragama Kristen di Jawa, Minahasa, dan Ambon;

3) KUH Perdata bagi warga negara Indonesia keturunan Eropa dan Cina, dan; 
4) Peraturan perkawinan campuran bagi perkawinan campuran.

Sangat terlihat jelas di sini bahwa tujuan dari UUP No. 1 tahun 1974 adalah unifikasi atau penyeragaman hukum yang sebelumnya sangat beragam. Idealnya, sebagai suatu produk hukum, UUP No. 1 tahun 1974 perlu dikaji sejauh mana efektifitasya dalam mengatur perilaku masyarakat di bidang perkawinan. Namun sampai kini setelah 32 tahun berlalu belum terlihat upaya-upaya serius untuk mengevaluasi sejauh mana efektifitas UUP No. 1 tahun 1974 sebagai sumber hukum dan apakah masih relevan digunakan sampai sekarang.

\section{Status Perempuan dan Tujuan Pembaruan Hukum Keluarga Islam}

Untuk merespon kenyataan yang terjadi di masyarakat, maka dilakukanlah usaha pembaruan terutama yang berkaitan dengan hukum keluarga dalam rangka mengangkat status perempuan. Meski sebenarnya pada dasarnya, Islam tidak mendiskriminasikan perempuan namun sampai sekarang banyak yang menganggap status mereka di bawah laki-laki dan tidak akan pernah sejajar. Keadaan perempuan semakin tersudutkan, mereka tidak boleh mendapatkan pendidikan, apalagi pekerjaan di luar rumah. Keadaan seperti ini menggugah hati para pejuang perempuan untuk meningkatkan status perempuan dengan menjaga dan memberikan hak-hak perempuan agar tidak terabaikan. Bentuk-bentuk pemeliharaan dan perlindungan hak-hak perempuan dapat diklasifikasikan dalam beberapa bentuk, yaitu:

a. Dalam bidang perkawinan

Bidang perkawinan memiliki beberapa hal yang dianggap mengacu pada pemeliharaan hak-hak perempuan (Luthfi, 2016):

1) Usia Perkawinan dan Perwalian

Dalam fikih hanya disebutkan akil balig tanpa ada umur yang pasti.

Secara alamiay akil balig ditandai secara biologis, bagi perempuan ketika sudah mengalami haid dan bagi laki-laki ketika mengalami mimpi basah. Beberapa negara muslim telah menetapkan batas usia seorang laki-laki dan perempuan untuk melangsungkan perkawinan. Tujuannya adalah untuk mengurangi dan menghapuskan praktik perkawinan anakanak dan melindungi kesehatan reproduksi perempuan. Sehingga, perkawinan yang belum memenuhi syarat usia tersebut dianggap tidak sah oleh hukum negara. Bahkan di negara tertentu diberikan sanksi pidana untuk perkawinan anak di bawah umur.

Sedangkan masalah perwalian, menjadi satu permasalahan yang sangat ditekankan di beberapa negara muslim. Tujuannya adalah untuk melindungi kepentingan perempuan; namun jika wali berbuat tidak adil dan tidak baik maka pengadilan dapat mengambil alih perwalian tersebut (Luthfi, 2016).

2) Masalah Poligami

Permasalahan poligami dalam hukum keluarga di dunia Islam terjadi perbedaan. Ada negara yang mengatur ketat bahkan larangan poligami, seperti Turki dan Tunisia yang dengan tegas melarang suami untuk berpoligami. Jika ketentuan tersebut dilanggar suami akan 
mendapatkan sanksi berupa denda. Akan tetapi ada juga negara yang tidak melarang poligami secara ketat, seperti Iran, Yaman Selatan, Maroko, dan Indonesia. Walaupun dengan persyaratan yang sangat ketat, seperti harus adanya izin atau persetujuan dari istri.

3) Perjanjian perkawinan dan taklik talak

Dahulu tidak dikenal perjanjian perkawinan dalam hukum perkawinan. Sekarang, perjanjian ini diadakan dengan tujuan untuk melindungi hakhak istri. Sepintas perjanjian ini mirip dengan taklik talak, namun kalau dicermati perjanjian perkawinan merupakan kesepakatan kedua belah pihak sebelum berlangsungnya akad nikah, di mana calon istri membuat perjanjian-perjanjian dengan calon suaminya selama tidak bertentangan dengan tujuan perkawinan. Perjanjian tersebut dapat berupa misalnya suami tidak menikah dengan perempuan lain atau tidak melarangnya keluar rumah. Sedangkan taklik talak merupakan ungkapan talak oleh suami jika suami tidak memenuhi perjanjian yang diikrarkannya. Seorang istri dapat menuntut cerai suaminya karena melanggar taklik talak.

4) Harta bersama

Kedudukan perempuan dalam perkawinan diperkuat dengan adanya ketentuan tentang harta bersama. Harta bersama merupakan harta yang diperoleh selama perkawinan berlangsung yang terpisah dari harta bawaan suami-istri. Kedua belah pihak mempunyai kewajiban dan hak yang sama di dalam memelihara dan membelanjakan harta tersebut. Syaratnya harus berdasarkan izin atau kesepakatan para pihak. Bagi istri diperbolehkan untuk mengajukan ke pengadilan untuk sita marital terhadap harta bersama karena keadaan suami yang melakukan perbuatan yang dapat menghabiskan harta bersama seperti pejudi, pemabuk dan lain-lain. Indonesia mengatur harta bersama dalam pasal 35-37 UU Perkawinan dan pasal 85-97 Kompilasi Hukum Islam.

b. Dalam Bidang Perceraian

Secara khusus di sini adalah perceraian yang terjadi atas inisiatif isteri. Hukum keluarga di negara muslim mengatur bahwa cerai tidak hanya bisa dilakukan dengan suami, tetapi juga dilakukan atas inisiatif istri dengan cerai gugat atau khulu'. Cerai gugat dapat terjadi ketika suami melanggar perjanjian perkawinan yang diikrarkan ketika akad nikah atau karena suami melanggar taklik talak seperti yang diatur dalam perundangan hukum keluarga Indonesia.

c. Dalam bidang hukum waris

Al-Quran menyebutkan bahwa bagian laki-laki adalah dua kali lipat dari bagian perempuan. Pemahaman yang dapat langsung ditangkap adalah bahwa laki-laki lebih tinggi posisinya daripada perempuan yang sekilas ayat ini seolah mendiskriminasikan perempuan. Melihat persepsi ini Turki 
dan Somalia mengatur sama bagian warisan laki-laki dan perempuan. Turki memberlakukan aturan tersebut sejak tahun 1926 yang diambil dari hukum perdata Swiss. Sementara Somalia mengaturnya dalam UU No. 23/1975 yang menyatakan bahwa laki-laki dan perempuan mempunyai hak yang sama dalam pembagian warisan.

Berbeda halnya dengan Indonesia yang tetap memberlakukan sesuai dengan nas sebagaimana yang dituangkan dalam KHI. Namun menurut M. Atho Mudzhar, ada kemungkinan penyamaan warisan antara laki-laki dan perempuan seperti di Minangkabau. Hal ini tentu tidak lepas dari keadaan socio-cultural masyarakat pada saat itu (Luthfi, 2016).

\section{Perempuan dan Pembatasan Usia minimal Kawin}

Pada periode klasik (610-650) tidak ada batasan usia perkawinan tegas, hanya saja Rasulullah pernah menikahi Aisyah pada usia 6 tahun dan mengumpulinya setelah Aisyah mengalami haid pada usia 9 tahun. Pada periode ini terjadi perbedaan pembatasan usia minimal dalam perkawinan, menurut Imam Hanafi batasan usia dini dalam perkawinan adalah saat seorang laki-laki mengalami mimpi basah (12 sampai 18 tahun) atau saat perempuan mengalami haid (9 sampai 17 tahun). Adapun menurut Imam Malik batasan minimal perkawinan adalah 17 tahun. Sedangkan Imam Syafi'I dan Hambali berpendapat bahwa batsan usia dini dalam perkawinan adalah 15 tahun (tnp, 2016: 1) Padangan ini bertahan sampai periode pertengahan (1250-1800 M). Ini karena pernyataan yang berkembang bahwa pintu ijtihad telah ditutup sehingga menimbulkan kemandekan 'berfikir'.

Pada periode modern $1800 \mathrm{M}$ dan seterusnya terjadi perkembangan pembatasan usia dini. Menurut Ulama Syafi'iyah batasan minimal perkawinan adalah 15 tahun, Ulama Hanafiyah menetapkan 17 tahun dan Ulama Malikiyah 18 tahun. Sedangkan Yusuf Musa menetapkan batasan usia minimal perkawinan 21 tahun dan Sarlito menetapkan minimal 25 tahun. Adapun menurut Dr. March Hendry Frank kematangan seseorang untuk melakukan pernikahan adalah usia 25 (dua puluh lima) tahun bagi laki-laki dan 20 (dua puluh) tahun bagi perempuan (tnp, 2016: 1)

Pada abad 20an, bersamaan dengan adanya pembaruan Hukum Keluarga Islam, maka salah satu poin pokoknya adalah pembatasan usia minimal kawin yang dituangkan dalam undang-undang (tnp, 2016: 1) Dengan adanya batasan umur ini, maka kekaburan terhadap penafsiran batas usia baik yang terdapat di dalam adat maupun hukum Islam dapat dihindari.

\section{Hubungan umur dengan beberapa faktor perkawinan}

Hubungan umur dengan beberapa faktor yang ada di dalam perkawninan di antaranya:

a. Hubungan Umur dengan Faktor Fisiologis dalam Perkawinan

Batasan hukum yang tercantum dalam UUP No. 1 tahun 1974 bila dikaji lebih lanjut, lebih menitik beratkan pada pertimbangan dari segi kesehatan fisiologis. Namun, usia dalam hubungan perkawinan tidak cukup dikaitkan hanya dengan segi fisiologis tetapi juga perlu dikaitkan dengan segi 
psikologis atau segi sosialnya. Selain itu, setelah dilakukan penelitian, perempuan yang hamil pada usia dini sangat beresiko. Apalagi jika kemampuan ekonomi tidak cukup baik sehingga akses kesehatan seperti pemantauan dan konsultasi dokter, nutrisi yang baik dan pengetahuan yang cukup menyebabkan resiko kehamilan menjadi lebih besar.

Pada usia 15-19, perempuan memiliki potensi dua kali lebih besar meninggal saaat melahirkan daripada yang berusia 20-25 tahun, di bawah itu (15 tahun) potensi meninggal bisa lima kali lebih besar. Perempuan muda yang sedang hamil, berdasarkan penelitian akan mengalami beberapa hal, seperti pendarahan, keguguran, dan persalinan yang lama atau sulit. Kondisi inilah yang menyebabkan ibu yang akan melahirkan bisa meninggal. Dari sisi kesehatan, pernikahan dini akan merugikan alat reproduksi perempuan karena makin muda menikah, semakin panjang rentang waktu bereproduksi. Sementara itu berdasarkan survey riset kesehatan dasar yang dilakukan pada 2013, permasalahan kesehatan reproduksi dimulai dengan adanya perkawinan dini (http://www.beritasatu.com/gaya-hidup/177423-beragam-efek burukpernikahan-dini.html diunduh pada 27 juni 2016).

Hasil penelitian juga menunjukkan bahwa salah satu faktor penyebab kanker serviks adalah aktivitas seksual di usia dini, sebab perempuan muda mempunyai kondisi leher rahim belum matang kanker serviks (kanker leher rahim). Kanker serviks merupakan kanker paling bebahaya bagi perempuan setelah kanker payudara. Kanker ini menyerang bagian terendah dari rahim yang menonjol di puncak liang senggama (Nasution, 2009: 382). Resiko lain yang muncul adalah trauma vagina. Ini akan menimbulkan infeksi karena lemahnya jaringan tissue yang belum diperkuat oleh hormon estrogen ini (Suryadilaga, 2009: 251).

b. Hubungan Umur degan Keadaan Psikologis dalam Perkawinan

Dilihat dari segi psikologis, wanita umur 16 tahun, belum bisa dikatakan telah dewasa. Demikian pula anak laki-laki umur 19 tahun (Walgito, 2000: 28). Dampak psikologis mereka yang menikah pada usia muda atau di bawah 20 tahun, secara mental belum siap menghadapi perubahan pada saat kehamilan. Persoalan lainnya adalah adanya perubahan peran, yakni belum siap menjalankan peran sebagai ibu dan menghadapi masalah rumah tangga. Banyak kasus perceraian yang terjadi pada pasangan yang usia kawinnya masih relatif muda.

c. Hubungan Umur dengan Kematangan Sosial, Khususnya Sosial Ekonomi dalam Perkawinan

Seseorang yang telah berani membentuk keluarga melalui perkawinan, segala tanggungjawab dalam hal menghidupi keluarga terletak pada pasangan bukan pada orang lain termasuk orangtua. Karena itulah dalam perkawinan masalah kematangan sosial-ekonomi perlu dipertimbangkan, karena akan berperan sebagai penyangga kehidupan keluarga. 
Jika dianalisi lebih jauh, peraturan batas usia perkawinan ini memiliki tujuan untuk mencegah pernikahan dini dan ini berkaitan cukup erat dengan masalah kependudukan dan kesejahteraan kaum perempuan. Dengan batasan umur, undangundang perkawinan bermaksud merekayasa untuk menahan laju perkawinan yang membawa pada laju pertambahan penduduk.

Pernikahan anak-anak adalah sebuah kejahatan karena anak anak dinilai belum siap reproduksinya untuk melaksanakan perkawninan (Gandhi, 2002: 65). Menikah di usia dini memiliki banyak kerugian bagi perempuan khususnya organ kesehatan reproduksi. Data dari UNICEF menunjukkan bahwa di tahun 2010 terdapat $60 \%$ anak perempuan di dunia menikah kurang dari umur 18 tahun. Sedangkan di Indonesia sebanyak 34,5\% anak perempuan menikah di bawah usia 19 tahun (http://www.beritasatu.com/gaya-hidup/177423-beragam-efek-burukpernikahan-dini.html diunduh pada 27 juni 2016). Bahaya melakukan pernikahan dini lainnya adalah semakin meningkatnya hubungan tanpa status yang menimbulkan banyaknya ragam penyakit, meningkatnya penindasan terhadap perempuan (KDRT), dan banyaknya kawin cerai yang merugikan pihak perempuan (Suyadilaga, 2009: 250).

Perempuan yang masih anak-anak tetapi melakukan pernikahan dini, beresiko melahirkan bayi prematur atau berat badan bayi yang dilahirkan sangat kurang dari normal. Ini bisa sangat berbahaya bagi bayi, bahkan memiliki resiko tinggi kerusakan otak dan mental. Bahkan karena pertumbuhan tulang belum lagi lengkap, resiko kerusakan tulang panggul sang ibu muda lebih tinggi, karena bayi yang keluar jauh lebih besar dari kemampuan tulang panggul sang ibu (Suyadilaga, 2009: 250). Sedangkan dampak bagi bayi adalah kelahiran prematur, berat badan kurang dari $2.5 \mathrm{~kg}$, dan kemungkian cacat bawaan akibat asupan gizi yang kurang.

Jadi jika dibandingkan dengan sebelum adanya pembaruan undang-undang hukum keluarga Islam, pengaturan tentang usia ini berpengaruh pada terpeliharanya hak-hak perempuan walau belum bisa maksimal. Masih ada celah untuk melakukan perkawinan dini. Meskipun batas umur perkawinan telah ditetapkan, namun prakteknya masih banyak terjadi perkawinan pada usia muda. Hal ini dikarenakan adanya UU modern tidak diikuti dengan perubahan sosial yang cukup memadai, UU ini berhasil hanya dalam jumlah yang terbatas (Nasution, 2002: 229). Usia minimal perkawianan di bawah 20 tahun juga sebaiknya perlu dikaji ulang untuk dilaksanakan pendewasaan. Karena dari tinjauan kesehatan, psikis dan sosial banyak ditemukan nilai madaratnya, terutama untuk kaum perempuan.

Perkawinan yang sukses pasti membutuhakan kedewasaan tanggungjawab secara fisik maupun mental untuk mewujudkn harapan yang ideal dalam kehidupan berumah tangga. Efektifitas ketentuan batas umur adalah tanggungjawab aparat, seperti kepala desa, pegawai pencatat nikah (PPN) dan PPPN, serta Pengadilan Agama. Demikian juga peran orangtua, keluarga, masyarakat, organisasi kemasyarakatan, organisasi sosial, dunia usaha, media massa, dan lembaga pendidikan. 


\section{Batas Usia Minimal Perkawinan dalam Hukum Keluarga Negara-Negara Muslim}

Terkait dengan batas usia perkawinan, antara satu negara dengan negara yang lain memiliki perbedaan. Adapun perbedaan tersebut dapat di jelaskan dalam tabel berikut (Mardani, 2011: 98):

\begin{tabular}{|c|c|c|c|}
\hline No & Negara & Dasar Hukum & Ketentuan \\
\hline 1 & Indonesia & $\begin{array}{l}\text { Pasal } 7 \text { UU No. } 1 \\
\text { tahun } 1974 \text { yang } \\
\text { diundangkan pada } \\
2 \text { Januari } 1974\end{array}$ & $\begin{array}{l}\text { Perkawinan hanya dijinkan jika } \\
\text { pihak pria sudah mencapai umur } 19 \\
\text { tahun dan pihak wanita sudah } \\
\text { mencapai umur } 16 \text { tahun (ayat } 1 \text { ). } \\
\text { Dalam hal penyimpangan terhadap } \\
\text { ayat } 1 \text { pasal itu dapat meminta } \\
\text { dispensasi kepada pengadilan ataua } \\
\text { pejabat lain yang ditunjuk oleh } \\
\text { kedua orangtua pihak maupun pihak } \\
\text { wanita (ayat 2). }\end{array}$ \\
\hline 2 & Malaysia & $\begin{array}{l}\text { UU keluarga Islam } \\
1984 \text { (Islamic } \\
\text { Family Law 1984) } \\
\text { pasal } 8\end{array}$ & $\begin{array}{l}\text { Tidak ada perkawinan dapat } \\
\text { dilangsungkan atau didaftarkan } \\
\text { dibawah UU ini dari mempelai laki- } \\
\text { laki berusia di bawah } 18 \text { tahun atau } \\
\text { perempuan di bawah umur } 16 \text { tahun } \\
\text { kecuali hakim syari'ah memberi izin } \\
\text { secara tertulis dalam kondisi tertentu. }\end{array}$ \\
\hline 3 & Aljazair & $\begin{array}{l}\text { The Family Law } \\
\text { Code } 1984 \text { pasal } 7 \\
\text { yang bunyinya: }\end{array}$ & $\begin{array}{l}\text { Usia sah dari perkawinan adalah } 21 \\
\text { tahun bagi laki-laki dan } 18 \text { tahun bagi } \\
\text { perempuan. }\end{array}$ \\
\hline 4 & Yordania & $\begin{array}{l}\text { The Code of } \\
\text { Personal Status } \\
1976 \text { pasal } 5\end{array}$ & $\begin{array}{l}\text { Untuk dapat melangsungkan } \\
\text { perkawinan kedua pasangan harus } \\
\text { sehat dan mempelai harus cukup } \\
\text { umur } 16 \text { tahun bagi laki-laki dan } 15 \\
\text { tahun bagi perempuan. }\end{array}$ \\
\hline 5 & Libanon & $\begin{array}{l}\text { The Law on Family } \\
\text { Right 1917-1962 } \\
\text { pasal } 4\end{array}$ & $\begin{array}{l}\text { Dipersayaratkan untuk dapat } \\
\text { dilangsungkan perkawian bahwa } \\
\text { seorang pria harus genap berusia } 18 \\
\text { tahun dan wanita } 17 \text { tahun. }\end{array}$ \\
\hline 6 & Tunisia & $\begin{array}{l}\text { pasal } 5 \text { ayat } 2 \text { Code } \\
\text { of Personal Status } \\
1956-1981\end{array}$ & $\begin{array}{l}\text { Seorang laki-laki yang belum } \\
\text { mencapai usia } 20 \text { tahun dan seorang } \\
\text { perempuan belum mencapai usia } 17\end{array}$ \\
\hline
\end{tabular}




\begin{tabular}{|l|l|l|l|}
\hline & & $\begin{array}{l}\text { tahun tidak dapat melangsungkan } \\
\text { pernikahan. }\end{array}$ \\
\hline 7 & Maroko & $\begin{array}{l}\text { Mudawwanah al- } \\
\text { ahwal al } \\
\text { syakhsiyyah tahun } \\
\text { 1957-1958, diatur } \\
\text { pasal 8 dan pasal 9. }\end{array}$ & $\begin{array}{l}\text { Usia perkawinan di Negara Maroko } \\
\text { adalah 18 tahun baik untuk laki-laki } \\
\text { maupun wanita. }\end{array}$ \\
\hline
\end{tabular}

\section{PENUTUP}

1. Kesimpulan

Berdasarkan pembahasan sebelumnya, dapat disimpulkan bahwa:

a. Pembaruan hukum keluarga Islam yang dilakukan oleh Turki, Mesir, Pakistan, Indonesia dan lain-lain adalah upaya untuk menjawab tantangan yang ada pada era modern karena fikih konvensional belum mampu untuk menjawabnya. Pembaharuan ini pada dasarnya bertujuan untuk mewujudkan masyarakat yang fleksibel. Perbedaan nalar fikih kontemporer dengan nalar fikih konvensional antara lain adalah nalar fikih kontemporer lebih bersifat kontekstual atau aktualitas teks dengan ciri mencari terobosan baru di tengah kemandegan hukum. Sedangkan nalar fikih klasik lebih bersifat tekstual/literal. Bentuk pembaruan hukum keluarga Islam ini ada dua yaitu Intra Doctrinal Reform dan Extra Doctrinal Reform. Tujuan dari pembaruan hukum keluarga Islam adalah untuk unifikasi hukum, pengangkatan status perempuan dan penyesuaian perkembangan zaman

b. Pembaruan hukum keluarga Islam di Indonesia dimulai tahun 1960 dengan adanya UU Perkawinan No. 1 tahun 1974. Aturan perkawinan ini pada dasarnya sudah banyak mengalami kemajuan jika dibanding dengan ketentuan fikih konvensional. Namun dalam hal pembatasan usia minimal perkawinan, pelaksanaannya belum bisa maksimal. Perlu adanya saksi yang tegas terhadap pelanggar undang-undang dan perlu kerjasama berbagai pihak. Tidak hanya itu peningkatan usia minimal kawin juga perlu dilakukan untuk meminimalisir dampak negatif terhadap perempuan.

\section{Saran}

Berdasarkan permasalahan yang ada, maka kajian ini memberikan saran sebagai berikut:

a. Pemerintah perlu untuk berperan serta dalam memamiksimalkan pelaksanaan aturan pembatasan usia minimal perkawinan.

b. Negara dituntut untuk dapat bersikap tegas terkait penjatuhan sanksi bagi siapapun ketika melanggar undang-undang. Secara khusus di sini adalah undang-undang atau peraturan yang berhubungan dengan perkawinan. 


\section{DAFTAR PUSTAKA}

\section{A. BUKU DAN MAKALAH}

Gandhi, Mahatma (2002). Kaum Perempuan dan Ketidakadilan Sosial. Yogyakarta: Pustaka Pelajar.

Jamaluddin, Nurun (2013). Sejarah Pembaruan Hukum Keluarga Islam: Konstribusi dan Tujuan Turki dan Mesir. Makalah disampaikan pada perkuliahan. Magister Hukum Islam UIN Sunan Kalijaga, Yogyakarta, 1 Oktober.

Mardani (2011). Hukum Perkawinan Islam di Dunia Islam Modern. Yogyakarta: Graha Ilmu.

Nasution, Khoiruddin (2002). Fazlur Rahman Tentang Wanita. Yogyakarta: Academia \& Tafazza.

Nasution, Khoiruddin (2009). Hukum Perdata (Keluarga) Islam Indonesia dan Perbandingan Hukum Perkawinan di Dunia Muslim. Yogyakarta: Academia \& Tafazza.

Nasution, Khoiruddin (2010). Pengantar dan Pemikiran Hukum Keluarga (Perdata) Islam Indonesia. Yogyakarta: Academia \& Tafazza.

Nasution, Khoiruddin (2012). Hukum Perkawinan dan Warisan di Dunia Muslim Modern. Yogyakarta: Academia \& Tafazza.

Prodjodikoro, Wirjono (2000). Hukum Perkawinan di Indonesia. Bandung: Vorink Van Hoeve.

Suryadilaga, M. Alfatih (2009). Efek Pernikahan Dini Sebuah Pertimbangan Bahaya Sosial dan Kesehatan. Jurnal Studi Gender dan Islam Al-Musawwa, Vol. 8, No. 2.

Walgito, Bimo (2000). Bimbingan dan Konseling Perkawinan. Yogyakarta: Andi Offset.

\section{B. PERATURAN PERUNDANG UNDANGAN}

Undang undang Nomor 1 tahun 1974 tentang Perkawinan.

Instruksi Presiden Nomor 1 tahun 1991 tentang Kompilasi Hukum Islam.

\section{Internet}

https://syakhsiyah.wordpress.com/2012/03/03/pembaruan-hukum-keluarga-dinegara-negara-muslim/. Diakses pada Senin 27 juni 2016.

http://www.arsip.badilag.net/artikel/6395-upaya-kesetaraan-gender-dalamrumusan-kodifikasi-hukum-keluaga-di-dunia-islam--olehharis-luthfi.html. Diunduh pada Senin 27 juni 2016.

http://www.beritasatu.com/gayahidup/177423-beragam-efek-burukpernikahandini.html. Diunduh pada Senin 27 juni 2016. 
